\title{
The Adsorption of Copper by SBA-15-CPTMS Mesoporous for Water Remediation
}

\author{
Donanta Dhaneswara ${ }^{1 *}$, Farhan Delayori ${ }^{1}$, Siti Utami $^{1}$, Falah Riski Kuskendrianto ${ }^{1}$, \\ Muhammad Hanif Abdurrahman ${ }^{1}$ and Jaka Fajar Fatriansyah ${ }^{1}$ \\ ${ }^{1}$ Department of Metallurgical and Materials Engineering, Faculty of Engineering, Universitas \\ Indonesia, Kampus Baru UI 16424 Depok, Jawa Barat, Indonesia
}

\begin{abstract}
The high development of science and technology affects the economic growth and industrialization process. The industrialization process produces industrial waste which contain heavy metal such as copper $(\mathrm{Cu})$. This industrial waste can harm the environment surronding industrial areas where 15 million or $6 \%$ of the Indonesian population live. In order to overcome this problem, mesoporous silica material Santa Barbara Amorphous-15 (SBA-15) is used as an adsorbent. SBA-15 was synthesized through sol gel process using tetraorthosilicate as precursor, Pluronic 123 triblock copolymer as template, and (3chloropropyl)trimethoxysilane (CPTMS) as functionalized agent. CPTMS was used to modify the SBA-15 surface in order to improve the materials as adsorbent. The materials were characterized using SAXRD and TEM to study material's cristallinity and pore structure, the presence of organic group was examined using FTIR, the surface area of SBA-15 and SBA-15 CPTMS were characterized using Brunauer Emmett Teller (BET) $\mathrm{N}_{2}$ adsorption isotherm test at $77 \mathrm{~K}$, and the ions concentration in solution after adsorption process was determined using AAS. The crystal structure of SBA-15 and SBA-15 CPTMS was found 2D heksagonal with a more regular SBA-15 pore structure than SBA-15 CPTMS. The surface area of SBA-15-CPTMS was found to be lower than SBA-15, $711.061 \mathrm{~m}^{2} / \mathrm{g}$ in comparison to $831.996 \mathrm{~m}^{2} / \mathrm{g}$. However, in copper adsorption test, it was found that SBA-15-CPTMS has higher adsorption ability.
\end{abstract}

\section{Introduction}

The high development in science and technology indirectly affected economic growth which is accompanied by rapid industrialization process in Indonesia. High industrialization rate in Indonesia is directly proportional to the level of environmental pollution [1]. It means that 15 million or $6 \%$ of the Indonesian population who live in industrial areas or surrounding areas can be affected by heavy metals massive pollution [2]. Environmental Pollution can be caused by heavy metals such as lead, copper, and cadmium which can be found in the water and soil. Pollution by these metals causes some disease in humans, because the excessive detoxification element is very dangerous to the human

\footnotetext{
* Corresponding author: farhan.delayori@ui.ac.id
} 
health [3]. Factories in industrial area of Jakarta-Bogor-Depok-Tangerang (Jabodetabek) continously disposes the liquid waste to the rivers nearby which finally empties at the Bay of Jakarta. In 2008 Jakarta bay has been greatly affected by heavy metals such as copper, cadmium, lead, mercury, and nickel [4].

Nanotechnology has been growing up very fast in Indonesia. Nanomaterials in Indonesia bring great benefits to human life because it has special properties compared to other materials. In this research, we use one of special nanomaterial which is material Silica SBA-15. SBA-15 is a silica mesoporous material which has ordered hexagonal pores structure, surface area of $400 \mathrm{~m}^{2} /$ gram [5], pores diameter between $5-15 \mathrm{~nm} \mathrm{[6],} \mathrm{and} \mathrm{also}$ has a good mechanical and thermal resistance because of the thickness wall SBA-15 between 3,1 - 6,4 nm [7]. A wide surface area makes SBA-15 widely used for adsorbent materials. In 2015 Mohammad Sadegh A. Et. Al has demonstrated the ability of SBA-15 as a lead nitrate heavy metal adsorbent. Metode Zhang et. Al is used as an example for SBA15 synthesis using amphiphilic triblock copolymers [8]. In 2016 synthesis of SBA-15 conducted by Donanta Dhaneswara et. Al has been successfully done with more simple method [9].

In this research, synthesis SBA-15 using pluronic 123 will use as copper heavy metals absorbent materials. It is expected that the level of metals pollution can be reduced significantly and then this materials can be applied to overcome the environmental pollution problem especially caused by liquid waste in Jabodetabek Industrial Area.

\section{Experimental}

\subsection{Materials}

Sol-gel process was used to synthesis SBA-15. Tetraethylorthosilicate (TEOS) by Merck as a precursor, Surfactant Pluronic 123 (P123) by Sigma Aldrich as a template, (3chloropropyl)trimethoxysilane (CPTMS) by Sigma Aldrich as Functionalizing Agent, $\mathrm{HCl}$ $2 \mathrm{M}$, Hydrous Toluene, and Copper Sulfate $\left(\mathrm{CuSO}_{4}\right)$ by Sigma Aldrich as adsorbate samples.

\subsection{Synthesis of SBA-15}

The Synthesis of SBA-15 was used by Sol-Gel Process. First, 4 grams of P123 was prepared and was dissolved in $100 \mathrm{~mL} 2 \mathrm{M} \mathrm{HCl}$, and then it was stirred at $40^{\circ} \mathrm{C}$ for duration 4 hours. After that, TEOS 6.3 grams was added slowly under static condition at $40^{\circ} \mathrm{C}$ for 24 hours. The resulting gel then was processed via hydrothermal method using Teflon Autoclave for crystallized the gel. The filtered white solid was washed with aquadest, air dried at room temperature, and calcined at $550^{\circ} \mathrm{C}$ for 5 hours.

\subsection{Functionalization of SBA-15}

(3-chloropropyl)trimethyloxysilane (CPTMS) is a functionalization agent for SBA-15 surface modification. The first step, SBA-15 (0.8 gr) was dissolved in hydrous toluene $(12.5 \mathrm{ml})$. After that, added 5.6 ml CPTMS under stirring condition. The functionalization process was carried out using reflux for 24 hours at $110^{\circ} \mathrm{C}$. Toluene and ethanol was used for washing the resulting white precipitate, next make 24 hours oven at $100^{\circ} \mathrm{C}$ for dry.

\subsection{Adsorption Process of Copper Ion}

The adsorption process was started by placing $\mathrm{Cu}^{2+}$ metal ion inside of six different bottles with concentration are 1000,2500 , and 7500 ppm for two of each bottle. Next, the bottle was placed on a magnetic stirrer with the addition of both SBA-15 as an adsorbent of 0.01 
gram at room temperature for 30 minutes. The second experiment was started by placing SBA-15 CPTMS and SBA-15 inside of six different bottles with concentration of 1000 , 2500 , and 7500 of each bottle. Then the bottle was placed on a magnetic stirrer with the addition of $\mathrm{Cu} 0.01$ gram at room temperature for 30 minutes. The last step was adsorption test using Atomic Adsorption Spectrometry (AAS) to find $\mathrm{Cu}^{2+}$ metal ion concentration which was absorbed by SBA-15.

\subsection{Characterization Methods}

SBA-15 and SBA-15 CPTMS surface area were determined by Brunauer Emmett Teller (BET) $\mathrm{N}_{2}$ adsorption isotherm test at $77 \mathrm{~K}$. Small Angle X-Ray Diffraction (SAXRD) was used to identify materials crystallinity, the SBA-15 organic group was determined by Fourier Transform Infrared (FTIR), and after adsorption ion concentration was identified by Atomic Adsorption Spectrometry (AAS). Transmission Electron Microscopy (TEM) was used to imaging the mesostructure of SBA-15.

\section{Results and discussion}

\subsection{The crystallinity of SBA-15 and SBA-15 CPTMS}

Fig. 1 is shown about the crystallinity of SBA-15 and SBA-15 CPTMS using Small Angle X-Ray Diffraction. In fig. 1, Sample SBA-15 and SBA-15 CPTMS show three main peaks (100), (110), and (200). The wide peak of SAXRD patterns of $2 \theta$ at around 0,3683 and the other peak at around 0.6547 for both materials. The three main peaks shown in SAXRD results, demonstrating the 2D ordered hexagonal pore structure arrays [10]. The (100) peak shows the surface wall of SBA-15 and for hexagonal structure is shown as peaks of (110) and (200) [11].

Based on fig. 1, The SAXRD peaks height for SBA-15 CPTMS is lower than SBA-15 peaks height. This is due to the alteration of ordered mesostructure SBA-15 which is the results of functionalization produced by organic groups throughout the SBA-15 mesoporous silica [11].

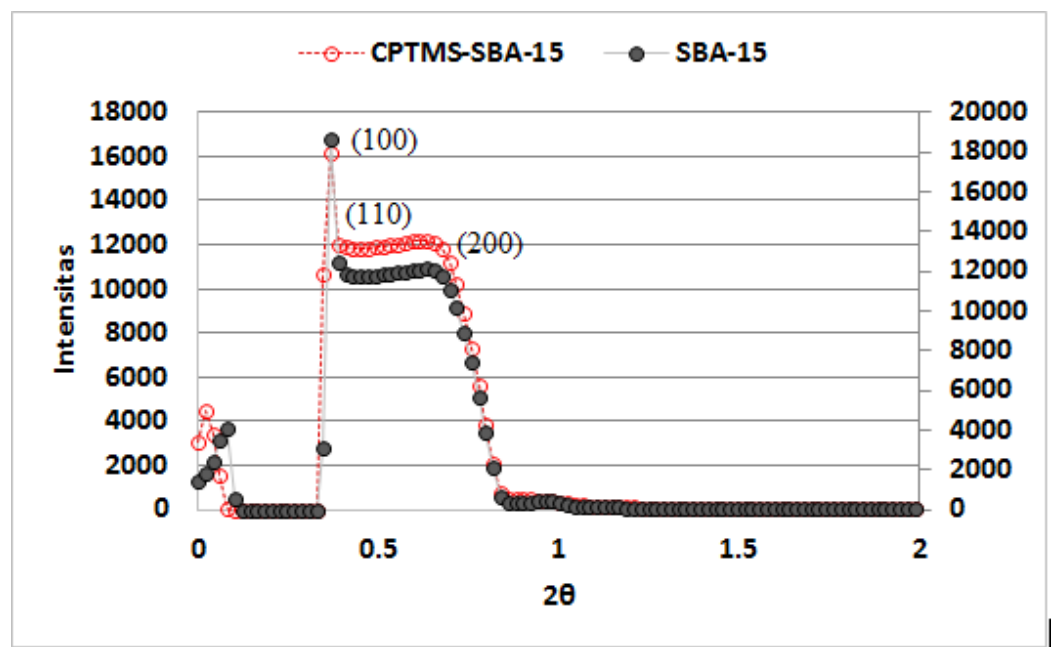

Fig. 1. The Small Angle X-Ray Diffraction plot of SBA-15 and SBA-15 CPTMS 
In fig. 2 below, the observation of the hexagonal structure of both material SBA-15 can be observed clearly. Fig. 2 shows of both SBA-15 has 2D hexagonal structure, as confirmed by Transmission Electron Microscopy (TEM) [12]. The high magnification of TEM can be used to observe the channel-like structures running parallel to the diagonal direction and the results show that the both materials have nanopores. As TEM result shown in figure 2(a) and 2(b), It indicates that SBA-15 CPTMS (fig. 2b) already made a bright surface compared to SBA-15 because of chlor and methyl modification.

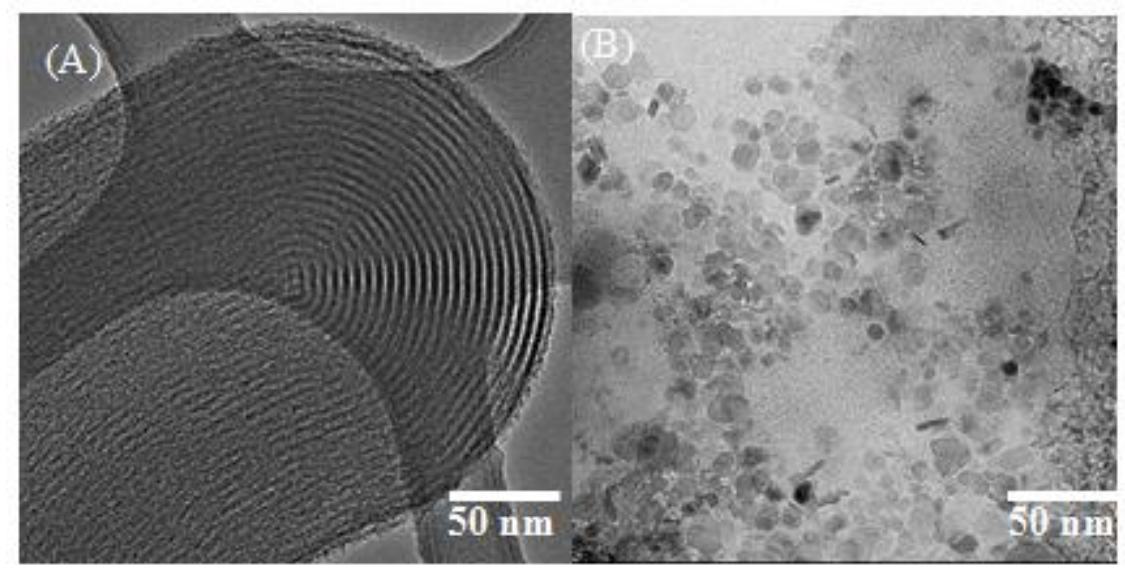

Fig. 2. The TEM results of (a) SBA-15 and (b) SBA-15 CPTMS

The white particle which is seen in the fig. 2(b) indicates that the particle dispersed around the SBA-15 CPTMS, but in fig. 2(a), those white particles can not be seen as. This possibly the presence of $\mathrm{Cl}$ which was brought by CPTMS.

\subsection{Material properties of SBA-15 and SBA-15 CPTMS}

Mesoporous silica SBA-15 has been successfully functionalized using functionalization agent (3-chloropropyl)trimethyloxysilane (CPTMS). The differences materials properties of SBA-15 and SBA-15 CPTMS as surface area, pore diameter and volume should be studied to know about ion cl effect on the surface of materials. The observation was using Brunauer Emmett Teller (BET) $\mathrm{N}_{2}$ adsorption isotherm test. This table below shows about surface area, pore volume and pore diameter of both material SBA-15.

Table 1. Material Properties of SBA-15 and SBA-15 CPTMS

\begin{tabular}{|lccc|}
\hline & $\begin{array}{c}\text { Pore Diameter } \\
(\mathrm{A})\end{array}$ & $\begin{array}{c}\text { Pore Volume } \\
(\mathrm{cc} / \mathrm{g})\end{array}$ & $\begin{array}{c}\text { Specific Surface } \\
\text { Area }\left(\mathrm{m}^{2} / \mathrm{g}\right)\end{array}$ \\
\hline \hline SBA-15 & $\mathbf{2 9 . 2 0 3}$ & $\mathbf{2 6 5 . 1 6 1}$ & $\mathbf{8 3 1 . 9 9 6}$ \\
SBA-15 CPTMS & $\mathbf{2 8 . 5 2 1}$ & $\mathbf{1 9 9 . 6 4 9}$ & $\mathbf{7 1 1 . 0 6 1}$ \\
\hline
\end{tabular}

Table 1 above shows that the differences materials properties between SBA-15 and SBA-15 CPTMS. It can be seen clearly that SBA-15 has smaller pore diameter that SBA-15 CPTMS. In comparison between SBA-15 and SBA-15 CPTMS, the reduction of pore volume and specific surface area of SBA-15 CPTMS were occurred at $25 \%$ and $15 \%$. 
Materials properties of both SBA-15 are related to the ability of adsorption that show in Fig. 3 below.

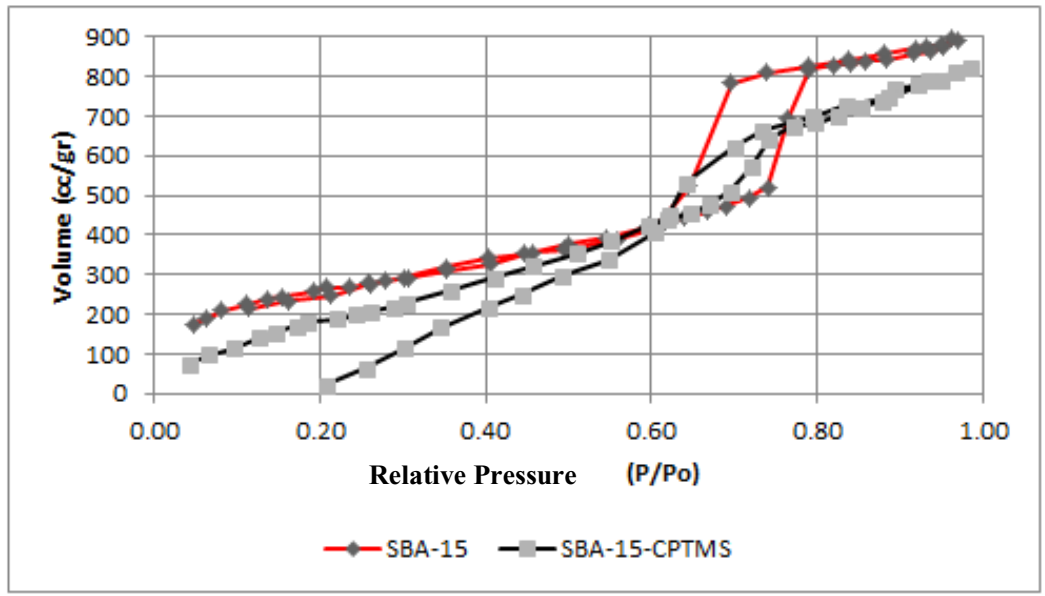

Fig. 3. The BET result $\mathrm{N}_{2}$ adsorption and desorption isotherm test.

Fig. 3 shows $\mathrm{N}_{2}$ adsorption-desorption isotherm of various SBA-15 concentrations. It can be seen from fig. 3 that there is one adsorption type for pure SBA-15 and CPTMS functionalized SBA-15. The type of adsorption-desorption curves for both SBA-15 is a type IV. Type IV corresponds to the condensation capillarity of the mesopores, it has shown on a steep slope and high relative pressure [13]. This type shows an adsorption mechanism which proceeds via multilayer adsorption [14]. Based on fig. 3, it can be seen that adsorption-desorption curve has a hysterical loop in the relative pressure range 0.6 to 0.8 for SBA-15 and 0.6 to 0.70 for SBA-15 CPTMS. There are four type of hysterical loop, based on the figure above for both materials SBA-15 it's clearly seen as Type H2 hysterical loop curves. Type $\mathrm{H} 2$ shows irregular size and shape pores SBA-15 [13].

Based on fig. 4, it can be known that the organic function makes the surface area of modified SBA-15 reduces to the half from the initial value even though the distribution is nearly similar. Fig. 4 shows that SBA-15 has pore diameter around $29 \AA$ and it means that pore size distribution SBA-15 is narrow. Based on analysis hysterical loop curve type H2 that shows irregular size and shape pores SBA-15, In fact for the prove SBA-15 CPTMS has more irregular structure that can be seen from the peak of SBA-15 CPTMS is lower than the peak of SBA-15 [15]. 


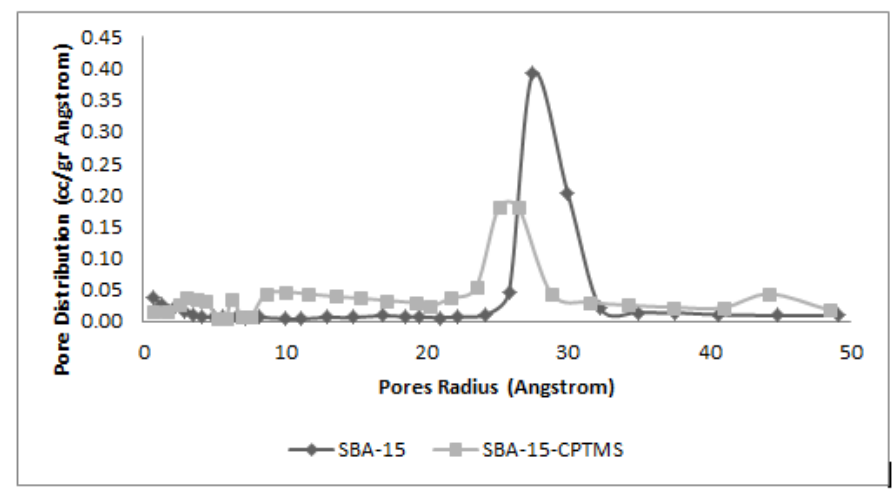

Fig. 4. The pore distribution of SBA-15 and SBA-15 CPTMS

\subsection{Organic group of SBA-15 and SBA-15 CPTMS}

Fig. 5 show abut FTIR results of both SBA-15 material. Symmetric-asymmetric stretching of the C-H Bonds can be observed from the typical bands at $2950-2850 \mathrm{~cm}^{-1}$ and vibration of Si-C bonds can be seen at bands $722 \mathrm{~cm}^{-1}$. The evidence regarding the success or failure of SBA-15 functionalization can be seen from the bands at $500 \mathrm{~cm}^{-1}$, in the figure below shows the existence of the $\mathrm{C}$ bond with $\mathrm{Cl}$ ion which means that the SBA-15 CPTMS functionalization has been successful.

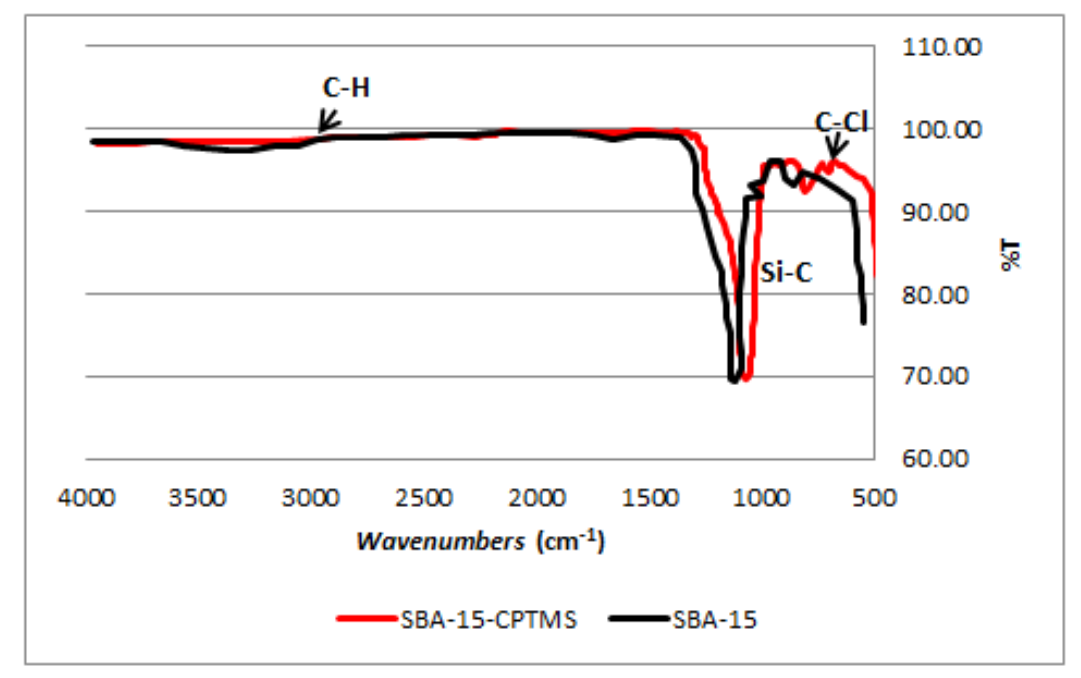

Fig. 5. FTIR spectra results of SBA- 15 and SBA-15 CPTMS

\subsection{The studies of $\mathrm{Cu}$ ion adsorption}

The ability of adsorption SBA-15 with fixed $\mathrm{Cu}$ concentration can be shown below. Based on table 2, the removal percentage of SBA-15 CPTMS is higher than SBA-15. It can be shown that the highest removal percentage of $\mathrm{Cu}$ obtained at the concentration of adsorban $7500 \mathrm{ppm}$. The increasing of adsorban concentration followed by the increasing removal percentage. 
Table 2. AAS result of varian concentration SBA-15 and SBA-15 CPTMS

\begin{tabular}{|c|c|c|c|c|}
\hline \multirow{2}{*}{ Samples } & $\begin{array}{c}\text { Samples } \\
\text { Concentration } \\
(\mathrm{ppm})\end{array}$ & \multicolumn{2}{|c|}{ Cu Final Concentration $(\mathrm{mg} / \mathrm{L})$} & \multirow{2}{*}{$\begin{array}{c}\text { Cu Removal } \\
(\%)\end{array}$} \\
\cline { 3 - 5 } & 1000 & $\mathrm{mg} / \mathrm{L}$ & $\%$ & 83.24 \\
\hline \multirow{3}{*}{ SBA-15 CPTMS } & 2500 & 1.0667 & 16.76 & 95.38 \\
\cline { 2 - 5 } & 7500 & 0.2939 & 4.62 & 98.11 \\
\hline \multirow{3}{*}{ SBA-15 } & 1000 & 4.6255 & 22.35 & 77.65 \\
\cline { 2 - 5 } & 2500 & 3.6088 & 17.43 & 82.57 \\
\cline { 2 - 5 } & 7500 & 3.0513 & 14.74 & 85.26 \\
\hline
\end{tabular}

Even though BET results has been shown that the modification of SBA-15 with CPTMS decreases the surface area, pore diameter, and pore volume, it does not mean that modification of SBA-15 yields lower capacity in adsorption. As fig. 6 shown, SBA-15 CPTMS has better adsorption capacity than pure SBA-15. This may be due to the modification of SBA-15 which generates of $\mathrm{O}-\mathrm{Si}-\mathrm{Cl}^{-}$bridge that makes adsorption better than the surface with only Si-O bond [16].

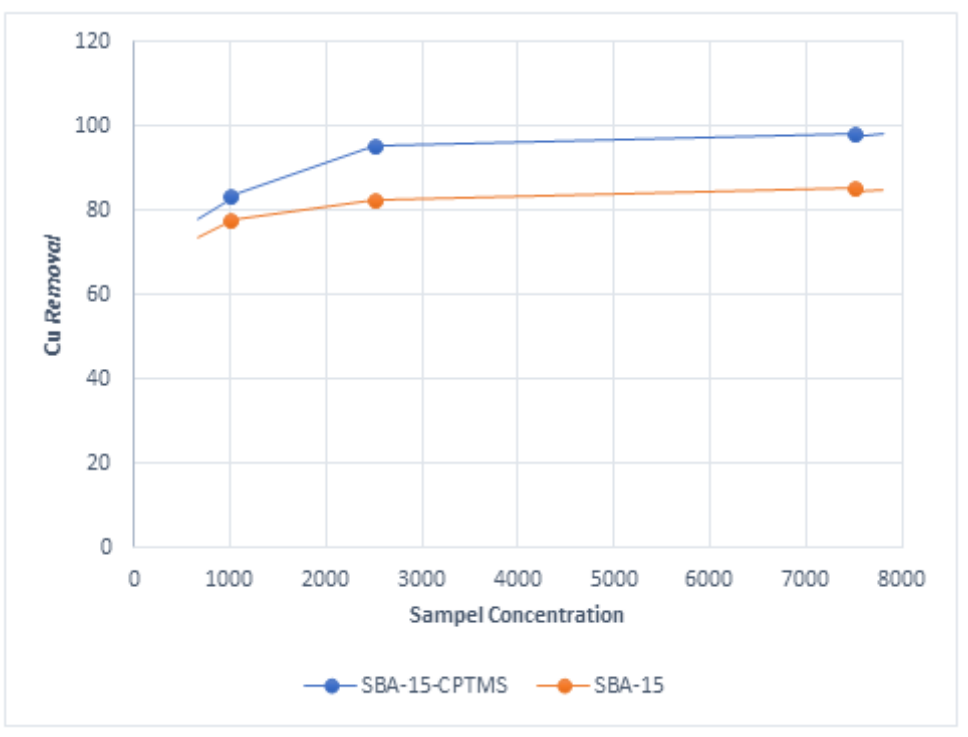

Fig. 6. Copper removal of SBA-15 and SBA-15 CPTMS

The other experiment was trying to fix concentration SBA-15 $(0,01 \mathrm{gr})$ with increasing concentration of copper ion from $1000 \mathrm{ppm}, 1250 \mathrm{ppm}$, and $1500 \mathrm{ppm}$. Table. 3 are shown the result, it's clearly seen that CPTMS functionalized SBA-15 has a better adsorption ability from the first concentration until the last concentration than pure SBA-15. As the result in the table below, for SBA-15 CPTMS increasing the adsorption ability from 3,99\% and reach the maximum at $9,95 \%$. On the other hand, pure SBA-15 starting point of adsorption ability is at $1,05 \%$ to maximum amount only $3,60 \%$. 
Table 3. The adsorption ability result of SBA-15 and SBA-15 CPTMS

\begin{tabular}{|c|c|c|c|}
\hline \multirow{2}{*}{ Samples } & $\begin{array}{c}\text { Cu Initial } \\
\text { Concentration } \\
(\mathrm{ppm})\end{array}$ & Final Concentration (ppm) & Adsorption (\%) \\
\hline \multirow{3}{*}{ SBA-15 CPTMS } & 1000 & 178.95 & 3,99 \\
\cline { 2 - 4 } & 1250 & 212,745 & 7,29 \\
\cline { 2 - 4 } & 1500 & 218,685 & 9,95 \\
\hline \multirow{3}{*}{ SBA-15 } & 1000 & 208,345 & 1,05 \\
\cline { 2 - 4 } & 1250 & 255.71 & 2,99 \\
\cline { 2 - 4 } & 1500 & 282.16 & 3,60 \\
\hline
\end{tabular}

According to the previous results, all of the concentration SBA-15 show a good result of $\mathrm{Cu}$ ion removal ability. In this part, $1000 \mathrm{ppm}$ of concentration SBA-15 has been chosen for second adsorption test with various metal copper ion and fix concentration of SBA-15. It can be observed from fig. 7 that as concentration of $\mathrm{Cu}$ ion was increased, percentage adsorption due to its $\mathrm{O}-\mathrm{Si}-\mathrm{Cl}$ chemical bridge was increased as well. The $\mathrm{Cl}^{-}$Organic group may induce better adsorption abilities with the extra addition of electron from the $\mathrm{Cl}$.

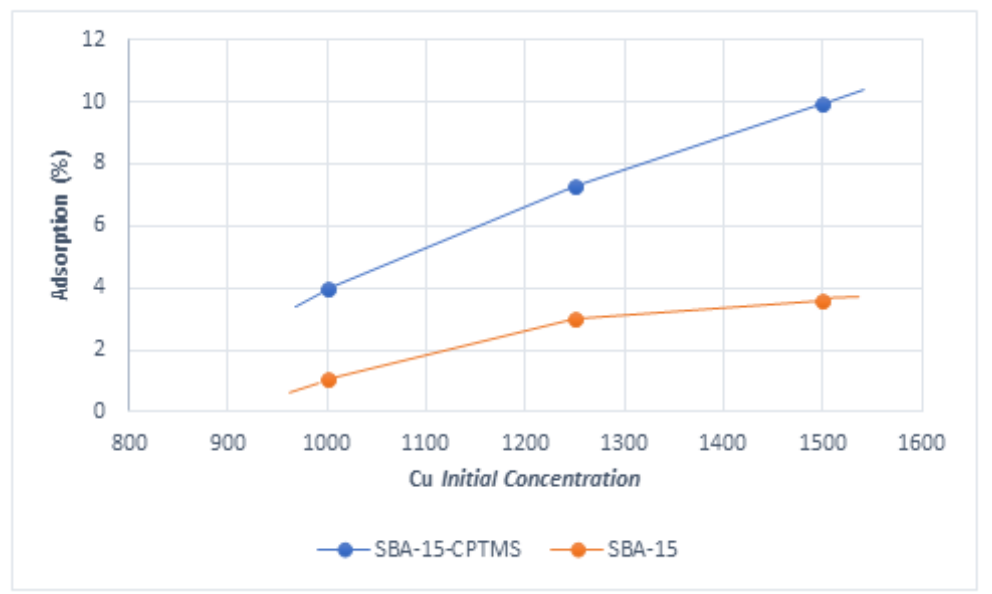

Fig. 8 The comparison of SBA-15 and SBA-15 CPTMS adsorption ability

\section{Conclusions}

SBA-15 has a 2D hexagonal structure based on Small-angle XRD. Functionalization SBA15 with CPTMS has been successfully conducted. It can be observed in a lower specific area, pore diameter, pore volume, and also the appearance of Si-Cl bond on the FTIR results. However, despite the lower mechanical properties of CPTMS functionalized SBA15 , the adsorption capability is higher than pure SBA-15. The adsorption of copper by SBA-15 CPTMS mesoporous for water remediation has been successfully conducted by using laboratory samples. The results showed that the CPTMS functionalized SBA- 15 for all concentration has a better adsorption ability than pure SBA-15 because of Si-Cl bond which is generated from the functionalization SBA-15 with (3 chloropropyl)trimethyloxysilane (CPTMS). 


\section{References}

1. S. C, S. and Z. Kamal, "Analisis Cemaran Logam Berat Pb, Cu, dan Cd Pada Ikan Air Tawar dengan Metode Spektrometri Nyala Serapan Atom (SSA)," in Seminar Nasional III SDM Teknlogi Nuklir, Yogyakarta, (2007).

2. C. B. o. Statistics, "Population Projection by Province, 2010-2035," Badan Statistik, Jakarta, (2015).

3. H. Palar, Pencemaran dan Toksikologi Logam Berat, Jakarta: PT. Rineka Cipta, (2012).

4. D. Jalius, D. Setiyanto, K. Sumantadinata, E. Riani and Y. Ernawati, "Akumulasi Logam Berat dan Pengaruhnya Terhadap Spermatogenesis Kerang Hijau (Perna Viridis)," Jurnal Ilmu-Ilmu Perairan dan Perikanan Indonesia, vol. 15, no. 1, pp. 77-83, (2008).

5. J. P. Thielmann, F. Girgsdies, R. Schlogl and C. Hess, "Pore Structure and Surface Area of Silica SBA-15: Influance of Washing and Scale-up," Beilstein Journal of Nanotechnology, vol. 2, no. 13, pp. 110-118, (2011).

6. D. Zhao, J. Feng, Q. Huo, N. Melosh, G. H. Fredrickson, B. F. Chmelka and G. D. Stucky, "Triblock Copolymer Syntheses of Mesoporous Silica with Periodic 50 to 300 Angstrom Pores," The American Association for the Advancement of Science, vol. 279, no. 548, pp. 548-553, (1997).

7. X. Li, S. Huang, Q. Xu and Y. Yang, "Preparation of WO3-SBA-15 mesoporous molecular sieve and its performance as an oxidative desulfurization catalyst," Transition Met Chem, vol. 34, pp. 943-947, (2009).

8. D. Zhao, Q. Huo, J. Feng, B. F. Chmelka and G. D. Stucky, "Nonionic Triblock and Star Diblock Copolymer and Oligomeric Surfactant Syntheses of Highly Ordered, Hydrothermally Stable, Mesoporous Silica Structures," Journal of The American Chemical Society, vol. 120, no. 24, pp. 6024-6036, (1998).

9. D. Dhaneswara and N. Sofyan, "Effect of Different Pluronic P123 Triblock Copolymer Surfactant Concentrations on SBA-15 Pore Formation," International Journal of Technology, vol. 7, no. 6, pp. 1009-1015, (2016).

10. F. Su, J. Zeng, X. Bao, Y. Yu, J. Y. Lee and X. S. Zhao, "Preparation and Characterization of Highly Ordered Graphitic Mesoporous Carbon as a Pt Catalyst Support for Direct Methanol Fuel Cell," Chem Matter, vol. 17, no. 15, pp. 3960-3967, (2005).

11. M. S. Asgari, A. Zonouzi, R. Rahimi and M. Rabbani, "Application of Porphyrin Modified SBA-15 in Adsorption of Lead Ions form Aqueous Media," Oriental Journal of Chemistry, vol. 31, no. 3, pp. 1537-1544, (2015).

12. M. V. Lombardo, M. Videla, A. Calvo, F. G. Requejo and G. A. Soler-Illia, "Aminopropyl-modified Mesoporous Silica SBA-15 as Recovery Agents of Cu(II)Sulfate Solutions: Adsorption Efficiency, Functional Stability and Reusability Aspects," Journal of Hazardous Materials, Vol. 223-224, pp. 53-62, (2012).

13. D. Dhaneswara, Studi Pengaruh Peningkatan Konsentrasi Surfaktan Pluronik P123 terhadap Karakteristik Pori Material SBA-15, Depok: Universitas Indonesia, (2006).

14. G. Cao, nanostructures and nanomaterials Synthesis, Properties, and Applications, London: Imperial College Press, (2004).

15. D. Dhaneswara, J. F. Fatriansyah, A. B. Mahagnyana, F. Delayori, D. A. Putranto and S. U. A. A. Anwar, "The Role of Modification SBA-15 Mesoporous Silica with CPTMS in Cd Adsorptions," in International Conference on Chemistry and Material Science 
(IC2MS), Malang, (2017).

16. M. Mureseanu, A. Reiss, I. Stefanescu, E. Davil, V. Parvulescu, G. Renard and V. Hulea, "Modified SBA-15 Mesoporous Silica for Heavy Metal Ions Remediation," Chemosphere, vol. 73, no. 9, pp. 1499-1504, (2008). 